\title{
Os Kaingang e a Usina Hidrelétrica do Apucaraninha ${ }^{1}$
}

\author{
The Kaingang and the Apucaraninha Hydroelectric Plant \\ Éder da Silva Novak* \\ https://orcid.org/0000-0002-5047-1471
}

\begin{abstract}
Resumo
A atual Terra Indígena Apucaraninha, situada no município de Tamarana (PR), possui uma área de 5.574 hectares e uma população de 1.700 indígenas da etnia Kaingang. Nesse território se localiza a Usina Hidrelétrica do Apucaraninha, construída a partir de 1946, pela Empresa Elétrica Londrina S/A (EELSA), responsável pelo fornecimento de energia elétrica para Londrina e região até o ano de 1974, quando foi encampada pela Companhia Paranaense de Energia (COPEL). O presente artigo, por meio de análise documental e pesquisa de campo com a prática de entrevistas orais, visa à compreensão das relações sócio históricas estabelecidas entre os Kaingang e os representantes do órgão indigenista e da EELSA. As ações dos indígenas asseguraram a demarcação da área como território indígena e as relações com os empregados da empresa despertaram nos Kaingang o sentimento de apropriação da usina, fundamentando suas reivindicações e negociações junto à COPEL.
\end{abstract}

Palavras-Chave: Povos indígenas; Hidrelétricas; Kaingang; Rio Tibagi.

\begin{abstract}
The current Apucaraninha Indigenous Land, located in Tamarana (PR), has an area of 5,574 hectares and a population of 1,700 Kaingang Indigenous people. In this territory is located the Apucaraninha Hydroelectric Power Plant, which was built in 1946 by the Electric Company Londrina S/A (EELSA), responsible for supplying electricity to the region of Londrina until 1974, when it was expropriated by the Paranaense Energy Company (COPEL). Through documentary analysis and field research, consisted of oral interviews, this paper aims to understand the socio-historical relations established between the Kaingang, and the representatives of the indigenous body, and EELSA. The actions of the indigenous ensured the demarcation of the area as an indigenous territory and the relations with the company's employees aroused in the
\end{abstract}

\footnotetext{
${ }^{1}$ Esse artigo é fruto da tese intitulada "Os Kaingang do Apucarana, o órgão indigenista e a usina hidrelétrica do Apucaraninha”, defendida em 2017, no Programa de Pós-Graduação em História da Universidade Federal da Grande Dourados (PPGH/UFGD), na linha História Indígena e do Indigenismo, sob a orientação do Professor Doutor Lúcio Tadeu Mota.

"Doutor em História pela UFGD. Professor da graduação e pós-graduação em História na Universidade Federal da Grande Dourados (UFGD). E-mail: edernovak@ufgd.edu.br
} 
Kaingang the feeling of ownership of the plant, motivating their claims and negotiations with the COPEL.

Keywords: Indigenous peoples; Hydroelectric Plants; Kaingang; Tibagi river.

\section{Introdução}

Na bacia do rio Tibagi, estado do Paraná, estão situadas cinco Terras Indígenas: Apucaraninha, São Jerônimo, Barão de Antonina, Mococa e Queimadas. A maior parte dos indígenas presentes nessas áreas é da etnia Kaingang, ${ }^{2}$ que habita a região há mais de dois mil anos, mas também há Guarani, Xokleng e Xetá. Há três décadas a Companhia Paranaense de Energia (COPEL) iniciou os estudos para a instalação de sete usinas hidrelétricas (UHEs) no rio Tibagi: Jataizinho, Cebolão, São Jerônimo, Mauá, Telêmaco Borba, Tibagi e Santa Branca. A maior parte das usinas ainda não saiu do papel, com inúmeras discussões sobre licenças ambientais e atritos com moradores locais e comunidades indígenas. Apenas a UHE de Mauá encontra-se em operação, depois de longa e tensa negociação com os indígenas e demais ribeirinhos e com a participação do Ministério Público Federal (MPF).

Estes conflitos e as negociações se espalharam por todo o vale do rio Tibagi e intensificaram a luta Kaingang da Terra Indígena (TI) Apucaraninha pelos seus direitos diante da presença da UHE do Apucaraninha, instalada na segunda metade da década de 1940, no interior do território indígena, na margem direita do rio Apucaraninha. ${ }^{3}$ Após o processo de redemocratização e da Constituição Federal (CF) de 1988, a comunidade indígena local passou a adotar diferentes estratégias para pressionar a COPEL a rever o contrato de arrendamento da área indígena utilizada pela usina.

Esse processo culminou na assinatura de dois Termos de Ajustamento de Conduta (TACs), com participação da COPEL, da Fundação Nacional do Índio (FUNAI), do MPF e da comunidade Kaingang do Apucaraninha. O primeiro deles, assinado em 2002, alterou o contrato de arrendamento, determinando os valores do MegaWatt/hora produzido e repassados aos indígenas. 0 segundo TAC, assinado somente em 2006, resultou em uma indenização de

\footnotetext{
${ }^{2}$ Kaingang é a quarta etnia indígena mais numerosa do Brasil, presente nos três estados da região sul e no estado de São Paulo. Sua língua é a Kaingang, pertencente ao tronco linguístico Macro-Jê, família Jê.

${ }^{3}$ Trata-se da primeira UHE, no Brasil, instalada em território legalmente reservado aos indígenas.
} 
R\$ 14 milhões de reais à comunidade indígena, pelos impactos ambientais, sociais, culturais e morais provocados pela construção, instalação e operação da usina, no período de 1946 a 2002.

No entanto, a forma como as ações foram divulgadas pelos meios de comunicação deturpa a atuação indígena, não revelando a historicidade dos Kaingang da região. Atribuiu-se ao grupo indígena a pecha de oportunistas, agressivos, violentos, como se não tivessem direitos às reivindicações. $O$ discurso que prevaleceu foi o de que a COPEL realizou uma boa ação, pagando um alto valor aos indígenas, que não teriam motivos para receber qualquer indenização ou compensação financeira. Por outro lado, interpretações do tipo "coitado dos indígenas", "sempre explorados", também foram comuns naquele momento. Novamente teve-se a ideia do indígena despolitizado, sem história, sem resistência, como um mero figurante, assistindo a tudo de maneira passiva.

A proposta aqui é apresentar os indígenas enquanto sujeitos históricos, elaboradores de estratégias políticas, como de forma precursora demonstraram Cunha ${ }^{4}$ e Monteiro. ${ }^{5}$ Inegavelmente, a construção de uma usina promove graves problemas às comunidades indígenas. Na atualidade, basta citar algumas pesquisas no caso da UHE de Belo Monte, como em Oliveira e Cohn ${ }^{6}$ e Domingues $^{7}$ ou em todo o contexto da região amazônica, como nos estudos de Paz. ${ }^{8}$ No caso da UHE Apucaraninha, embora com dimensões muito menores que Belo Monte, não foi diferente. Contudo, não se pode ficar aprisionado às abordagens vitimizadoras sobre os indígenas na história do Brasil. Os pressupostos teóricos e metodológicos da história indígena, construídos nesses últimos trinta anos, exigem apresentar os índios enquanto protagonistas de suas histórias e participantes da formação histórica do Brasil, como enfatizou Monteiro. ${ }^{9}$

O caso Apucaraninha exige uma análise apurada dos acontecimentos desde o contexto de construção da usina em 1946. A resistência indígena e suas políticas estratégicas não surgiram apenas às vésperas das assinaturas

\footnotetext{
${ }^{4}$ CUNHA, Manuela Carneiro da. (Org.). História dos índios no Brasil. São Paulo: Cia. das Letras, 1992.

${ }^{5}$ MONTEIRO, John Manuel. Os negros da terra: índios e bandeirantes nas origens de São Paulo. São Paulo: Companhia das Letras, 1994.

${ }^{6}$ OLIVEIRA, João Pacheco de; COHN, Clarice. (Orgs.). Belo Monte e a Questão Indígena. Brasília-DF: ABA. 2014. ${ }^{7}$ DOMINGUES, William César Lopes Cachaça. Concreto e Sangue! Saúde, Alcoolismo e Violência. Povos Indígenas no Contexto da Hidrelétrica de Belo Monte. Dissertação (Mestrado) - Universidade Federal do Pará, Instituto de Filosofia e Ciências Humanas, Programa de Pós-Graduação em Antropologia, Belém, 2017.

${ }^{8}$ PAZ, Luciana Rocha Leal da. Hidrelétricas e Terras Indígenas na Amazônia: Desenvolvimento Sustentável? Tese (Doutorado) - Universidade Federal do Rio de Janeiro (COPPE/UFRJ), Rio de Janeiro, 2006.

${ }^{9}$ MONTEIRO, John Manuel. o desafio da história indígena. In: SILVA, Aracy Lopes da; GRUPIONI, Luís Donizete Benzi (Orgs.). A temática indígena na Escola. MEC, Brasília, 1995, p. 221-228.
} 
dos TACs, como procuram afirmar alguns meios de comunicação e a própria COPEL, em clara tentativa de descaracterizar a luta histórica dos Kaingang da TI Apucaraninha, no município de Tamarana - Paraná.

Torna-se mister compreender a história dos Kaingang do Apucarana ${ }^{10} \mathrm{e}$ todas as suas ações estabelecidas perante a construção, instalação e o funcionamento da usina no território indígena. Trata-se de uma história conturbada, recheada de conflitos, que precisa ser detalhada, articulando todos os sujeitos envolvidos, portadores de projetos políticos antagônicos, com interesses divergentes e, dessa forma, promovendo um cenário de tensões e de jogo de ideias. Mas também história com momentos de convergências de interesses, em que se definem alianças, acordos e aproximações. O objetivo principal é evidenciar a participação do sujeito histórico indígena, tradicionalmente omitido das narrativas que retratam a história do Paraná e do Brasil como um todo.

Com esta finalidade, as atenções nesse artigo se concentram no período entre os anos de 1946 a 1974, respectivamente o marco inicial das obras da UHE, aproveitando a queda d'água do Salto Apucaraninha (ver Fotografia 1), e o momento em que a COPEL encampou a Empresa Elétrica Londrina S/A (EELSA), responsável pela construção da hidrelétrica e por sua operação até 1974. A metodologia consistiu na análise de diferentes documentos do Serviço de Proteção aos Índios (SPI), especificamente relacionados ao Posto Indígena (PI) Apucarana, assim como a documentação da EELSA e COPEL e do governo do estado do Paraná. Além disso, as pesquisas de campo e as entrevistas realizadas com membros da comunidade Kaingang do Apucaraninha, entre os anos de 2014 a 2017, foram fundamentais para os resultados alcançados nesse estudo.

\section{Problemática: o protagonismo Kaingang}

Os estudos sobre a história da usina do Apucaraninha não demonstram a participação dos indígenas no processo de construção do empreendimento hidrelétrico. Primeiramente, algumas exaltações foram elaboradas à usina

\footnotetext{
${ }^{10} \mathrm{~A}$ história de mais de dois mil anos da presença Kaingang na bacia do rio Tibagi pode ser consultada em: NOVAK, Éder da Silva. Emã e Tekoha: territórios indígenas e a política indigenista. Curitiba: Appris, 2019; NOVAK, Éder da Silva; MOTA, Lúcio Tadeu. A política indigenista e os territórios indígenas no Paraná (1900-1950). Revista Fronteiras. Dourados, MS. v. 18, n. 32. p. 76-97. jul./dez. 2016; MOTA, Lúcio Tadeu. As guerras dos índios Kaingang: a história épica dos índios Kaingang no Paraná (1769-1924). 2. ed. Maringá: Eduem, 2009; MOTA, Lúcio Tadeu. As colônias indígenas no Paraná provincial. Curitiba: Aos Quatro Ventos, 2000; MOTA, Lúcio Tadeu. A Guerra de Conquista nos Territórios dos Índios Kaingang do Tibagi. Revista de História Regional. Ponta Grossa, vol. 1, p. 187-207, jan./jun. 1997; TOMMASINO, Kimiye. A história dos Kaingang da bacia do Tibagi: uma sociedade Jê meridional em movimento. Tese (Doutorado em Antropologia), Universidade de São Paulo, São Paulo. 1995.
} 
no Salto Apucaraninha, omitindo qualquer informação sobre os indígenas da localidade, destacando apenas as ações da EELSA e da COPEL. ${ }^{11}$

\section{Fotografia 1: Salto Apucaraninha}

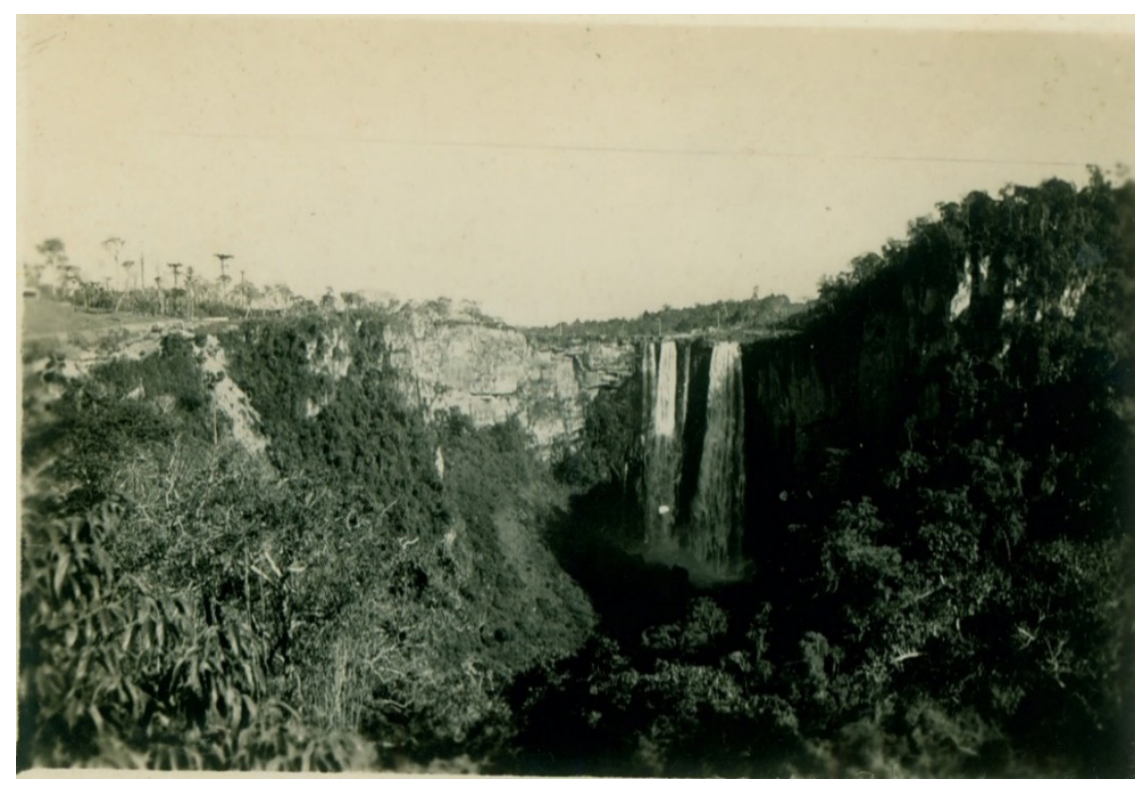

Fonte: Museu Histórico de Londrina - UEL. ${ }^{12}$

Em segundo, as discussões em torno da questão "Hidrelétricas e Povos Indígenas", a partir de meados da década de 1970, promoveram alguns estudos e a produção de laudos e relatórios, na perspectiva de criticar a construção e a presença da UHE do Apucaraninha, mantendo uma visão essencialista sobre a história e a cultura da comunidade indígena local, reproduzindo uma

\footnotetext{
${ }^{11}$ É escassa a produção acadêmica sobre a história da energia elétrica no Paraná. Algumas obras existentes foram elaboradas por cronistas, jornalistas ou por representantes do próprio setor elétrico. Vale destacar a presença de grandes acervos documentais, como a biblioteca do Polo Atuba, em Curitiba - PR, da COPEL, que podem ser utilizados pelos historiadores para o avanço das pesquisas no tema história da energia elétrica. Em relação a ELLSA e a UHE Apucaraninha algumas obras, no sentido apologético e que não demonstram a presença indígena, podem ser consultadas: ANDREOLI, Arturo. A história da energia elétrica no Estado do Paraná. Companhia Paranaense de Energia Elétrica (COPEL). Histórico. Curitiba: 2004; RECCO, Rogério. Clareira Flamejante: o Norte do Paraná antes e após o advento da energia elétrica. Maringá: Gráfica e Editora Midiograf, 2007; SIQUEIRA, Márcia D. et al. Um século de eletricidade no Paraná. Curitiba: Universidade Federal do Paraná, 1994.

${ }^{12}$ Foto retirada na década de 1940 pelo engenheiro responsável pela construção da usina. Ver: ACERVO FOTOGRÁfICO. Coleção Luiz Muraska. Museu Histórico de Londrina Padre Carlos Weiss - Universidade Estadual de Londrina (UEL).
} 
análise apenas dicotômica e vitimizadora do processo, na qual os indígenas perderam suas terras, seus costumes, suas rendas, seus alimentos etc. sendo "transferidos do local em que estava erguida a maioria de suas aldeias, para junto do Salto Apucaraninha". ${ }^{13}$ Em virtude dos projetos de colonização "[...] os Kaingang foram transferidos desse local e assentados junto ao rio Apucaraninha, nas proximidades da usina, construída em 1946". ${ }^{14}$

Por último, alguns pesquisadores, de diferentes áreas do conhecimento, têm se interessado por questões atuais da TI Apucaraninha ou por temas que acabam envolvendo os Kaingang da bacia hidrográfica de todo o rio Tibagi, fazendo breves menções sobre o período de construção e de instalação da usina no rio Apucaraninha, sem pormenorizar a relação da comunidade indígena com os representantes do empreendimento hidrelétrico. ${ }^{15}$

Outrossim, tanto as abordagens apologéticas em relação à UHE do Apucaraninha, quanto às versões essencialistas e vitimizadoras, não colocam os indígenas enquanto sujeitos históricos. Também não contextualizam aquele acontecimento com a política de reestruturação dos territórios indígenas, por intermédio do Acordo de $1949,{ }^{16}$ que culminou na expropriação da maior parte das áreas indígenas presentes no Paraná, inclusive o território Kaingang do Apucarana (Ver Mapa 1). São análises que omitem a participação da comunidade Kaingang em todo o processo histórico estudado, colocando os indígenas apenas nos bastidores da história, distantes dos palcos e das cenas principais, como afirma Almeida. ${ }^{17}$

\footnotetext{
${ }^{13}$ HELM, Cecília M. Vieira. Conflitos Sociais entre Indígenas e não Indígenas no Processo de Negociação sobre Compensações de Usinas Hidrelétricas implantadas em Terras Indígenas. In: $1^{\varrho}$ Encontro Ciências Sociais e Barragens. Universidade Federal do Rio de Janeiro, IPPUR/UFRJ. Rio de Janeiro, 08 a 10 de junho de 2005. p. 8. ${ }^{14} \mathrm{Ibidem}$, p. 10.

${ }^{15}$ BIASETTO, Eliane Aparecida. O Rio Tibagi e suas representações: a polêmica da água e o desenvolvimento do Projeto Tibagi (1970-2000). Dissertação (Mestrado em História Social), Universidade Estadual de Londrina, Londrina. 2014; RAMOS, Luciana Maria de Moura. Vénh Jykré e Ke Há Han Ke: Permanência e Mudança do Sistema Jurídico dos Kaingang no Tibagi. Tese (Doutorado em Antropologia Social), Universidade de Brasília, Brasília. 2008; RODRIGUES, Diego Campos Arruda. Concepções e práticas agroflorestais na terra indígena Kaingang Apucaraninha (Paraná). Dissertação (Mestrado em Ciências Sociais), Universidade Estadual de Londrina, Londrina. 2008; DUARTE, Amauri. Projeto da Usina Hidrelétrica São Jerônimo: conflitos e contrastes. Dissertação (Mestrado em Geografia), Universidade Estadual de Maringá, Maringá. 2004.

${ }^{16}$ O Acordo de 1949, estabelecido entre o governo da União e o Serviço de Proteção aos Índios (SPI), representou o momento auge da expropriação dos territórios indígenas no estado do Paraná e ocorreu concomitantemente aos anos de construção e instalação da usina do Apucaraninha sob o comando da EELSA. No caso do Território Indígena Apucarana o Acordo estabelecia a redução de uma área com mais de 68 mil hectares, reservada ainda em 1900, para apenas 6.300 hectares. Maiores detalhes sobre esse processo de esbulho consultar: NOVAK, Éder da Silva. Os Kaingang e a reestruturação do Território Indígena Apucarana (PR) no século XX. Territórios e Fronteiras (UFMT. Online), v. 11, 2018, p. 279-307.
}

${ }^{17}$ ALMEIDA, Maria Regina Celestino de. Os índios na história do Brasil. Rio de Janeiro: Ed. FGV, 2010. 
Não se trata de negar os interesses da concessionária de energia elétrica, do governo do Paraná, das frentes colonizadoras e do órgão indigenista. Nem tampouco recusar os danos provocados pela usina do Apucaraninha e pelo processo de esbulho do Território Indígena Apucarana. Destarte, não se trata de omitir os impactos da hidrelétrica na forma de vida dos indígenas da localidade, mas de historicizar a sua presença, demonstrando as relações e ações de todos os sujeitos envolvidos naquele contexto histórico.

Dessa forma, qual foi a leitura realizada pelos Kaingang daquele contexto? Quais suas ações perante a presença da usina e seus representantes? E suas articulações em virtude do processo de reestruturação dos seus territórios e do avanço das frentes colonizadoras, somado ao fato da construção do empreendimento hidrelétrico? E suas relações com os empregados da usina?

As respostas a esses questionamentos revelam um intercruzamento de ações da comunidade indígena, superando a visão polarizada da história e as interpretações vitimizadoras, que tratam a história como uma via de mão única. O emaranhado de estratégias e os múltiplos interesses entre os sujeitos envolvidos no processo de construção da UHE Apucaraninha demonstram uma história como via de mão dupla, que se cruza, com rupturas, alianças, traições, com relações complexas e dinâmicas, caracterizando o que Balandier ${ }^{18}$ chamou de "Situação Colonial", complementada pela ideia de "Situação Histórica", definida por Oliveira. ${ }^{19}$

\section{A ação indígena nos documentos}

A usina fica pouco mais de um quilometro acima da barra do rio Apucaraninha no rio Tibagí, tudo lado direito, em terras da reserva indígena como já disse. Notei que não tem embaraçado em nada a marcha dos serviços do Posto, pois, fica distante deste cerca de 25 quilometros [...] Não obstante ser distante do toldo mais próximo de 12 a $15 \mathrm{Kts} .{ }^{20}$

Conforme o documento do SPI, o Salto Apucaraninha, local escolhido para a construção da usina, ficava de 12 a $15 \mathrm{~km}$ do Toldo (Emã) ${ }^{21}$ indígena mais

${ }^{18}$ BALANDIER, Georges. El concpeto de situación colonial. Ciudad de México, 1972.

${ }^{19}$ OLIVEIRA, João Pacheco de. O nosso governo: os Ticunas e o regime tutelar. São Paulo: Marco Zero, 1988.

${ }^{20}$ SPI, 30/03/1947. Relatório SPI. Filme 73, Fotograma 1644. Museu do Índio, Rio de Janeiro.

${ }^{21}$ Toldo ou Emã (na língua Kaingang) era o local com moradias de grupos Kaingang, conjunto de suas habitações. O Território Indígena Apucarana, situado na margem esquerda do rio Tibagi, conforme Mapa 1, era constituído de diversos Toldos (Emãs), demonstrando uma significativa presença dos Kaingang por todo aquele território em meados do século XX. 
próximo. Certamente, essas distâncias não consideravam os deslocamentos dos indígenas, sua forma de vida diferenciada, seus ranchos temporários de caça, coleta, pesca etc. Entretanto, é nítido o não reconhecimento, pelo órgão indigenista, da presença indígena nas proximidades do local onde se encontrava a queda d'água utilizada pelo empreendimento hidrelétrico.

O SPI, atendendo as determinações do Acordo de 1949, elaborou a proposta de reestruturação do Território Indígena Apucarana, em duas áreas, conforme o Croqui presente na Imagem 1, que também demonstra os Toldos ou Emãs espalhados pela área, conforme levantamentos realizados pelos agentes do SPI. Os Emãs são os pequenos triângulos desenhados no Croqui pelo representante do órgão indigenista. Nota-se uma concentração de Toldos próxima da confluência do rio Apucarana com o rio Tibagi e em sua margem esquerda, que ficaria fora das áreas reservadas, pintadas a lápis em formato retangular. ${ }^{22}$

Imagem 1: Croqui dos Toldos e das áreas propostas ao PI Apucarana em $14 / 03 / 1950$

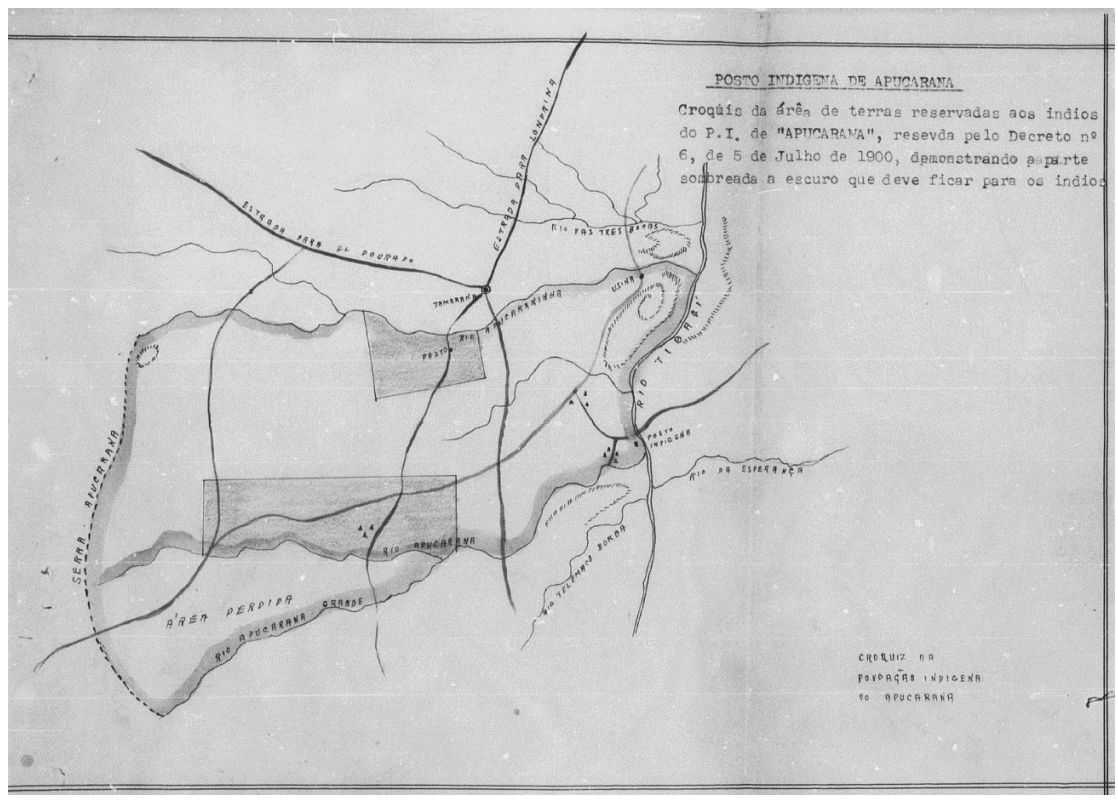

Fonte: SPI, 14/03/1950. ${ }^{23}$

\footnotetext{
${ }^{22} \mathrm{~A}$ comparação da Imagem 1 com o Mapa 1 facilita a compreensão dos limites do Território Indígena do Apucarana e a perda da maior parte de suas terras em comparação com a atual TI Apucaraninha, assim como a localização dos Emãs Kaingang em todo o território indígena no contexto de construção da usina. ${ }^{23}$ SPI, 14/03/1950. Croquis. Filme 76, Fotograma 251. Museu do Índio, Rio de Janeiro.
} 
Portanto, não havia Toldos nas proximidades do Salto Apucaraninha, onde estava em andamento as obras do empreendimento hidrelétrico, conforme se observa no Croqui, escrito o termo "usina" no rio Apucaraninha, próximo de sua foz no rio Tibagi. Destarte, não é apenas a documentação do SPI que revela a não existência dos Emãs nas proximidades do local da usina, antes do início de sua construção. A memória indígena, também deixa claro que o Toldo Apucaraninha, presente no Mapa 1, apenas passou a existir após o início das obras do empreendimento hidrelétrico. Quando perguntado sobre o local da usina, o Sr. Raul Pereira informou: “[...] era vazia lá antes, depois que construiu essa usina e é antiga né [...] eles tinha morado tudo já pra cá [...] é a usina, começou [...] não foi começado ainda naquele tempo, daí depois, depois quando vieram, eles começou a fazer a usina". ${ }^{24}$

Essa informação é importante para compreender a política indígena desenvolvida a partir do início da construção da UHE, conforme detalhada adiante. As áreas inicialmente pretendidas pelo órgão indigenista, pintadas no Croqui acima, estariam distantes da usina em construção. Entretanto, como será demonstrado, o jogo de interesses entre os Kaingang e os representante dos SPI e da EELSA e suas ações estratégicas definiram mudanças no processo de territorialização daquela espacialidade, em que os indígenas tiveram um papel de destaque.

O órgão indigenista reconheceu o erro nas delimitações de uma das áreas e propôs a revisão dos limites. Isto ocorreu em outubro de 1950, após o SPI constatar que alguns Toldos ficariam de fora da área proposta, sugerindo novos limites:

Desta forma os dois toldos maiores de índios ficarão dentro da área, evitando-se os inconvenientes, e o que é mais impossível de transferir todos esses índios, ainda que perto como é, relativamente, isso eu o afirmo porque tive ocasião de observar dos índios dali. ${ }^{25}$

Conforme passagem do documento acima, o inspetor do SPI deixou evidente a resistência dos grupos indígenas em sair dos seus territórios tradicionalmente ocupados.

[...] os índios ficariam fora da terra a ser-lhes demarcada, a qual abrangeria também o bairro da Igrejinha, povoado de

\footnotetext{
${ }^{24}$ PEREIRA (2017). Entrevista com Raul Pereira. Entrevistador: NOVAK, Éder da Silva. Terra Indígena Apucaraninha - Município de Tamarana, 28 de março de 2017.

${ }^{25}$ SPI, 12/10/1950. Ofício no 26 e Croquis. Filme 76, Fotogramas 269-272. Museu do Índio, Rio de Janeiro.
} 
sertanejos. Este fato, causaria grandes despesas para o Estado, e para a Inspetoria, e sérios aborrecimentos, devido a dificuldade de mudança dos índios como também dos sertanejos a serem transferidos. ${ }^{26}$

Outrossim, o órgão indigenista tinha experiências frustrantes na tentativa de deslocar os indígenas, com extrema dificuldade de retirá-los dos seus Toldos. ${ }^{27}$ Conquanto, o SPI elaborou um novo Croqui com as áreas propostas para o Território Indígena Apucarana, incluindo as localidades do bairro do Fihú e da usina, conforme Croqui da Imagem 2. Os triângulos no Croqui indicam a presença dos Kaingang nas proximidades do local do canteiro de obras da usina, ou seja, uma parte dos indígenas adotou a estratégia de se deslocar para as proximidades da hidrelétrica em construção, compondo seus Emãs na margem direita do rio Apucaraninha, enquanto demais grupos permaneceram nos outros Toldos espalhados por todo o Território Indígena Apucarana.

Imagem 2: Croqui dos Toldos e das áreas propostas ao PI Apucarana em $12 / 10 / 1950$

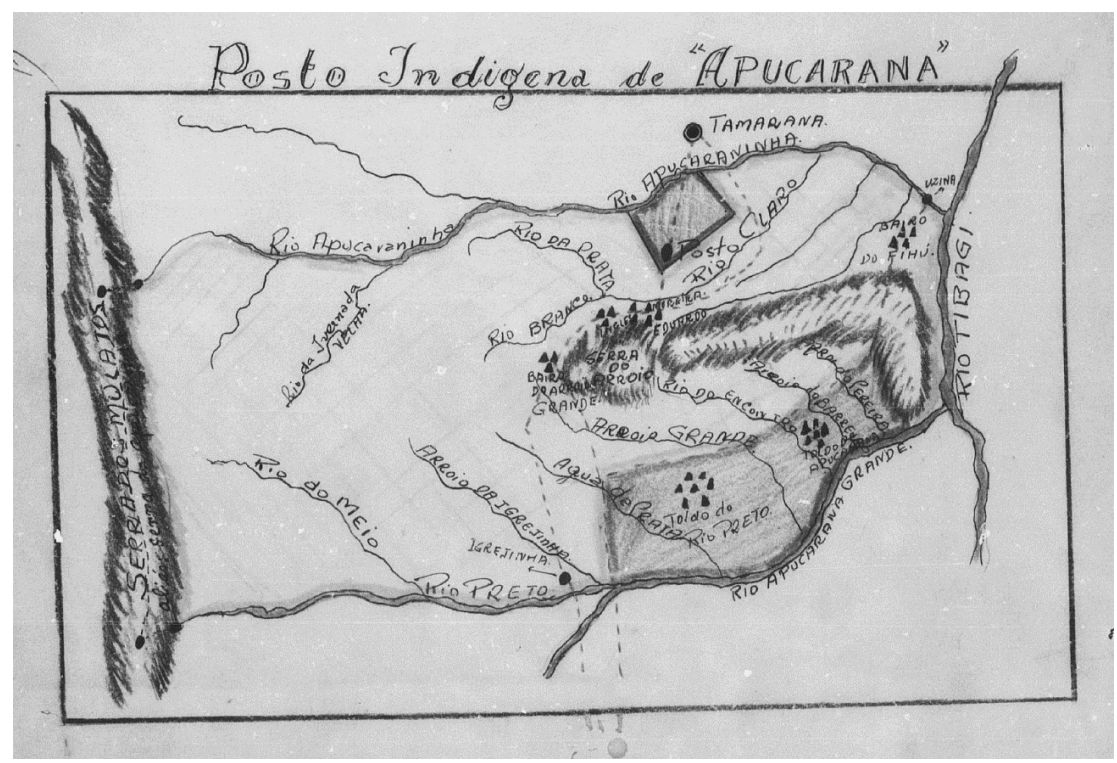

Fonte: (SPI, 12/10/1950). ${ }^{28}$

\footnotetext{
${ }^{26}$ SPI, 22/12/1950. Atas de Reunião. Filme 48, Fotograma 1468. Museu do Índio, Rio de Janeiro.

${ }^{27}$ Para maiores detalhes dessa resistência indígena frente às tentativas de deslocamentos dos seus territórios pelos agentes do SPI, ver: NOVAK; MOTA, 2016, op. cit.
}

${ }^{28}$ SPI, 12/10/1950, op. cit. 
Importante enfatizar que a ação Kaingang de se deslocar para próximo da usina e construir seus Emãs na localidade, influenciou de forma direta a decisão do SPI em definir os novos limites da área a ser destinada aos Kaingang do Apucarana, estabelecendo que o local próximo do empreendimento hidrelétrico fosse considerado território indígena, assim como motivou o SPI a alterar a sede do PI Apucarana, em 1952, para próximo da usina. Dessa forma, o órgão indigenista abandonou a ideia de duas áreas separadas e constituiu o Território Indígena A pucarana em uma única área, conforme Mapa $1,{ }^{29}$ ficando com a posse das terras utilizadas pela UHE Apucaraninha. Esse Mapa apresenta todo o processo de desterritorialização do Território Indígena Apucarana, bem como a localização de todos os Emãs Kaingang daquele território, inclusive o Toldo Apucaraninha, composto por parte dos Kaingang após o início das obras da usina.

\footnotetext{
${ }^{29}$ Os Mapas 1 e 2 são resultados do cruzamento das informações da documentação do SPI e dos 4 anos de pesquisa de campo com a comunidade Kaingang da TI Apucaraninha, com deslocamentos dos pesquisadores e dos indígenas por todo o antigo Território Indígena do Apucarana. Foram utilizadas as Cartas Geográficas dos Municípios Paranaenses, a Base Hidrográfica do Estado do Paraná, no caso, a Bacia do Rio Tibagi, o programa ArcGIS para a elaboração dos Mapas. Todas as informações obtidas em campo eram gravadas, o local era fotografado e era usado um GPS para coletar as coordenadas da localidade para depois, no laboratório de pesquisa, alimentar os Mapas com os pontos obtidos. Dessa forma, os dois Mapas presentes nesse artigo, são georreferenciados e possuem exatidão nas informações quanto ao local representado.
} 
Mapa 1: Os Toldos indígenas e a (des) territorialização dos Kaingang do Apucarana

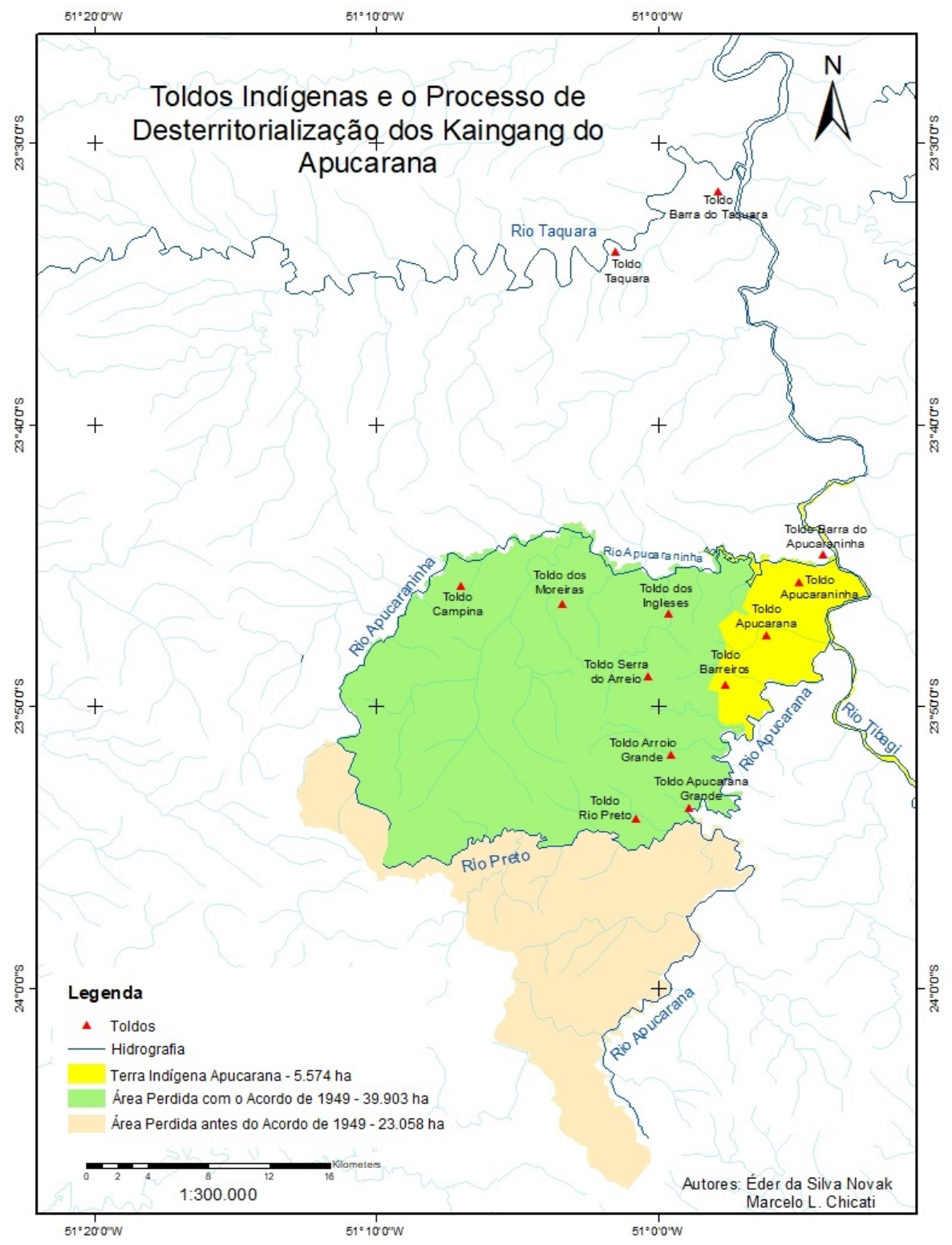

Autores: Éder da Silva Novak e Marcelo L. Chicati. 


\section{A memória indígena: territórios, festas e deslocamentos}

Se por um lado, algumas famílias indígenas se deslocaram para próximo da usina em construção, por outro, os Kaingang não abandonaram os seus Toldos de outrora, estabelecendo suas políticas para fazer frente ao processo de esbulho dos seus territórios. As ações indígenas, o jogo de interesses, as alianças, os conflitos, lutas, conquistas e perdas estão presentes na memória da comunidade, que conta suas histórias para as novas gerações, contemplando sentimentos diversos: indignação pela perda substancial das terras; saudosismo dos seus locais antigos de moradias, de rituais e de festas; tristeza pela morte de parentes e de amigos; mas também sentimentos de força pela histórica luta do seu povo, de esperança em obter novamente os seus territórios perdidos e de luta pela melhoria da qualidade de vida da comunidade.

As entrevistas com os indígenas e os deslocamentos por todo o antigo Território Indígena Apucarana, na companhia dos Kaingang, permitem afirmar que eram muitos os locais habitados - conforme ficou evidenciado no Mapa 1 - por eles no momento em que se iniciou a construção da usina do Apucaraninha. ${ }^{30}$ A memória indígena também evidencia os locais de suas festas, encontros, rituais e como ocorriam seus deslocamentos por toda a bacia do rio Tibagi, interligando os Kaingang das duas margens desse rio. A memória da comunidade indígena ainda guarda com saudosismo esses encontros e festas, na época em que o território era extenso e farto de alimentos, frutos, peixes, animais para caça etc.

As informações dos entrevistados revelam também as relações entre os diferentes Toldos e seus integrantes, o conhecimento de todo aquele território, as conexões que ultrapassavam as fronteiras da área reservada aos indígenas, interligando com os territórios de Mococa e Queimadas e do outro lado do rio Tibagi, com Barão de Antonina e São Jerônimo, indicando os pontos de travessias no rio Tibagi e os locais de festas como a Água do Encontro, a Festa da Piracema e a Festa do Pari no rio Taquara, conforme Mapa 2.

\footnotetext{
${ }^{30} \mathrm{Um}$ agradecimento especial a toda comunidade indígena da TI Apucaraninha, em especial aos entrevistados e guias: Elói Zacarias Nogueira Pipir, Gilda Kuitá, João Krág Mág Cardoso Neto, José Ekór Bonifácio, Pedro Kagre Kãg Candido de Almeida, Raul Pereira, João Maria Rodrigues Tapixi. Suas narrativas durante os deslocamentos pela TI atual e por toda a área expropriada durante o século XX foram fundamentais para elaboração desse texto.
} 
Mapa 2: Os pontos de travessia e as festas dos Kaingang do Apucarana

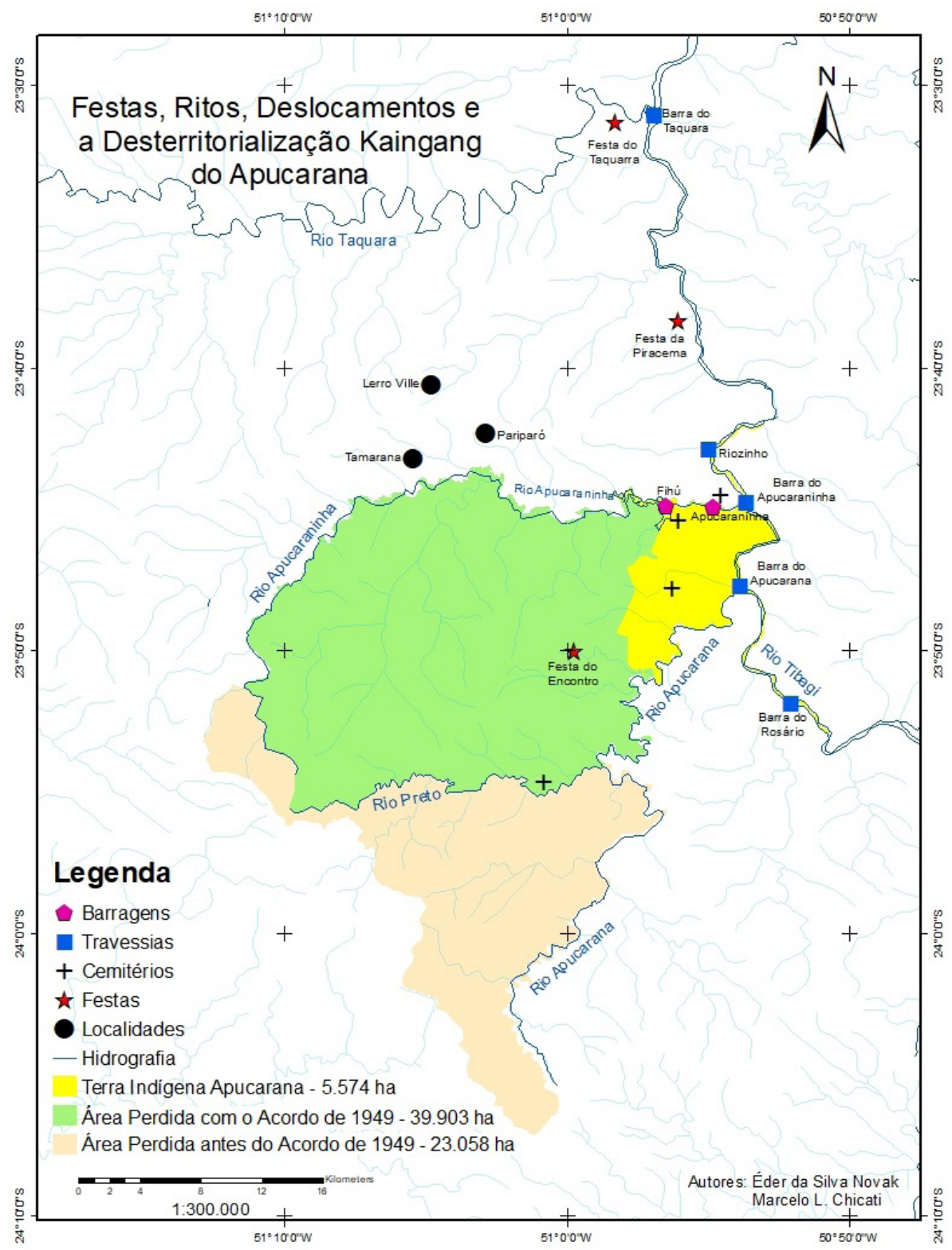

Autores: Éder da Silva Novak e Marcelo L. Chicati. 
A memória da comunidade indígena da TI Apucaraninha revela também a resistência dos Kaingang em sair dos seus Toldos e suas estratégias de aproximação das obras da usina e da nova sede do PI Apucarana, nas margens do rio e do Salto Apucaraninha. Inicialmente, durante a segunda metade da década de 1940, ocorreu o deslocamento de algumas famílias indígenas para próximo da usina em construção, com seus interesses e razões, constituindo seus Toldos em local ainda não habitado pelos Kaingang. Na sequência, décadas de 1950 e 1960, com a instalação da nova sede do Posto, as migrações e os deslocamentos dos indígenas para essa localidade se intensificaram.

Não obstante, muitos grupos resistiram em sair de suas áreas tradicionalmente ocupadas e alguns que se deslocaram inicialmente para próximo da usina, acabaram retornando para seus Toldos ou outras áreas destinadas aos indígenas, como São Jerônimo, Mococa, Queimadas, Ivaí, entre outras. ${ }^{31}$

o SPI procurava agrupar os indígenas na nova sede do PI Apucarana e a forma de convencimento era a possibilidade de estudar na escola, ter acesso a remédios e atendimento no postinho de saúde, ganhar uma casa do órgão indigenista, obter trabalhos remunerados etc. Estas propostas despertaram o interesse de algumas famílias indígenas, que aos poucos foram se concentrando nas margens do rio Apucaraninha. Entretanto, muitos outros Kaingang negavam as ordens dos agentes do SPI e não saíam dos seus Toldos. Conforme demonstra Novak, ${ }^{32}$ durante as negociações para o cumprimento do Acordo de 1949 , as tentativas de agrupar os Kaingang promoveram conflitos e o deslocamento de famílias indígenas para outros territórios dos rios Tibagi e Ivaí.

Outrossim, tratava-se de uma estratégia de luta pela terra e de sobrevivência, adotada pelos indígenas naquele momento, aproximando-se da usina, trabalhando, fazendo trocas comerciais, promovendo relações sociais com os empregados, assegurando a propriedade daquela faixa territorial, que possibilitaram as reivindicações diversas junto à concessionária de energia elétrica, inclusive, o próprio fornecimento de eletricidade, alguns anos após.

Inegavelmente, a redução do Território Indígena Apucarana provocou o empobrecimento da comunidade indígena local e inúmeras dificuldades para manter suas formas de vida. Entretanto, foram quase duas décadas de resistência para não sair dos seus Toldos antigos, mesmo em contexto muito desfavorável, com as articulações políticas entre o órgão indigenista e os

\footnotetext{
${ }^{31}$ Trata-se de informações constantes nas entrevistas que podem ser consultadas com detalhes em: NOVAK, Éder da Silva. Os Kaingang do Apucarana, o órgão indigenista e a usina hidrelétrica do Apucaraninha. Tese (Doutorado em História). Universidade Federal da Grande Dourados, Dourados - MS, 2017.

${ }^{32}$ NOVAK, 2018, op. cit.
} 
governos federal e estadual. Conforme Relatório Mensal, em 7 de dezembro de 1967, a área situava-se no Município de Londrina, Distrito de Tamarana, com Certificado de Escritura Pública, registrada no $5^{\circ}$ Tabelião, em Curitiba. ${ }^{33}$ Conquanto, somente após o Golpe Civil Militar e a extinção do SPI, o novo órgão indigenista (FUNAI), com suas ações intensas de perseguição, ameaças e mortes, utilizando a força dos seus coronéis e generais, conseguiu delimitar a área indígena em seus 6.300 hectares, estabelecidos pelo Acordo de $1949 .{ }^{34}$

\section{A política indígena em relação à UHE do Apucaraninha}

A leitura dos documentos e as entrevistas orais evidenciam a política dos indígenas perante a presença da UHE do Apucaraninha. Dessa forma, distante de abordagens polarizadas da história, que simplesmente dicotomizam a relação indígenas e não-indígenas, a proposta aqui é revelar as ações estratégicas dos primeiros, demonstrando que diante da política indigenista também se faz presente a política indígena.

De fato, a presença da UHE do Apucaraninha, em terras pertencentes aos Kaingang do Apucarana, não pode ser analisada como se a hidrelétrica impusesse aos indígenas uma mudança dos seus territórios ou expulsasse os grupos indígenas das proximidades da usina. Na verdade, verifica-se o deslocamento de famílias indígenas para mais próximo da usina, conforme registrado pelo agente do SPI: "[...] assim como observei que os Engenheiros e empreiteiros de vários serviços, dão preferencia de trabalho aos índios que por ali aparecem". ${ }^{35}$

Se por um lado, a ação colonizadora não pode ser esquecida, em todas as suas fases da "Guerra de Conquista", ${ }^{36}$ por outro, não se tem como negar que a presença da usina despertou o interesse de algumas famílias indígenas, que fizeram sua leitura do ocorrido e elaboraram suas políticas próprias para se relacionarem com o novo sujeito ali presente. Mas o que promoveu o deslocamento de grupos indígenas para próximo do local de construção da UHE do Apucaraninha? Quais foram os seus interesses? Como se deram as relações sócio históricas entre indígenas e empregados da EELSA?

\footnotetext{
${ }^{33}$ SPI, 07/12/1967. Relatório Mensal de Novembro de 1967. Filme 71, Fotograma 1720. Museu do Índio, Rio de Janeiro.

${ }^{34} \mathrm{Em}$ mais um capítulo do processo de expropriação do Território Indígena Apucarana, nos anos 1970, a comunidade Kaingang perdeu mais de 700 hectares, ficando com seus atuais 5.574 ha (ver Mapas 1 e 2).

${ }^{35}$ SPI, 30/03/1947, op. cit.

${ }^{36}$ SOUZA LIMA, Antonio Carlos de. Um grande cerco de paz: poder tutelar e indianidade no Brasil. Petrópolis: Vozes, 1995.
} 
Os Kaingang se aproximaram da hidrelétrica com a finalidade de desempenhar trabalhos remunerados na derrubada da mata, abertura das estradas e no canteiro de obras para a construção da usina, além de realizar suas trocas comerciais. Com o estabelecimento do contato com os empregados da EELSA, os indígenas passaram a participar de atividades cotidianas de lazer, como os bailes, o futebol, entre outras, juntamente com o novo sujeito presente em seu território. Estas ações asseguraram a eles a posse das terras onde se localiza a hidrelétrica. Esse fator desenvolveu na comunidade indígena local o sentimento de apropriação da usina, fundamentando suas contínuas reivindicações junto à concessionária de energia elétrica e ao órgão indigenista.

A documentação do SPI evidencia que a EELSA utilizou mão de obra indígena em algumas atividades para a construção da usina.

Satisfazendo seu pedido verbal para informar sobre a construção ou montagem da usina da "Empreza Elétrica de Londrina S/A", em terras do P.I.T. de Apucarana, [...] vendo mais ou menos seguinte: [...] assim como observei que os Engenheiros e empreiteiros de vários serviços, dão preferencia de trabalho aos índios que por ali aparecem, assim como fui informado que os administradores não admitem a venda de bebidas alcóolicas, principalmente aos índios, medida que a muito vem este serviço adotando. Devo dizer mais uma ves, que não ouvi nenhuma queixa de que essa Empreza esta perturbando a marcha dos serviços do Posto ou dos índios, de certo modo até tem dado alguns resultados, dando serviços e comprando os produtos dos índios, não obstante ser distante do toldo mais próximo de 12 a 15 Kts. ${ }^{37}$

O documento deixa claro a não existência de Toldos nas proximidades do local da usina até o momento da visita do agente do SPI, ao PI Apucarana, no segundo semestre de 1946. O Mapa 1, georreferenciado, apresenta o Toldo Apucaraninha distante apenas a um km do Salto Apucaraninha, local da usina. Portanto, trata-se um Emã construído pelos Kaingang após o início das obras do empreendimento hidrelétrico. Na verdade, reduziu-se a distância entre o local da usina e dos Toldos devido à ação dos próprios indígenas.

Além do trabalho remunerado, o documento denota que os Kaingang vendiam e trocavam seus produtos junto aos empregados da usina e agentes da EELSA. É interessante observar que, enquanto os agentes do órgão indigenista solicitava uma vistoria para ver a local da usina, mostrando, de início, desconhecimento em relação as obras, alguns indígenas já estavam envolvidos

${ }^{37}$ SPI, 30/03/1947, op. cit. 
com os trabalhos na proximidade do Salto Apucaraninha, negociando sua mão de obra, realizando suas vendas e trocas e se relacionando com os empregados da concessionária.

O documento revela ainda que, aos olhos do órgão indigenista, a presença da hidrelétrica poderia colaborar com a política indigenista integracionista, por meio da prática do trabalho, já que os representantes da EELSA concediam serviços aos Kaingang que ali apareciam..$^{38}$ Por outro lado, os indígenas também se interessaram pelas atividades no canteiro de obras, oferecendo-se como mão de obra em vários serviços, como será evidenciado nas entrevistas a seguir.

Fotografia 2: Instalações técnicas, área de residência e duto em construção da Usina do Apucaraninha

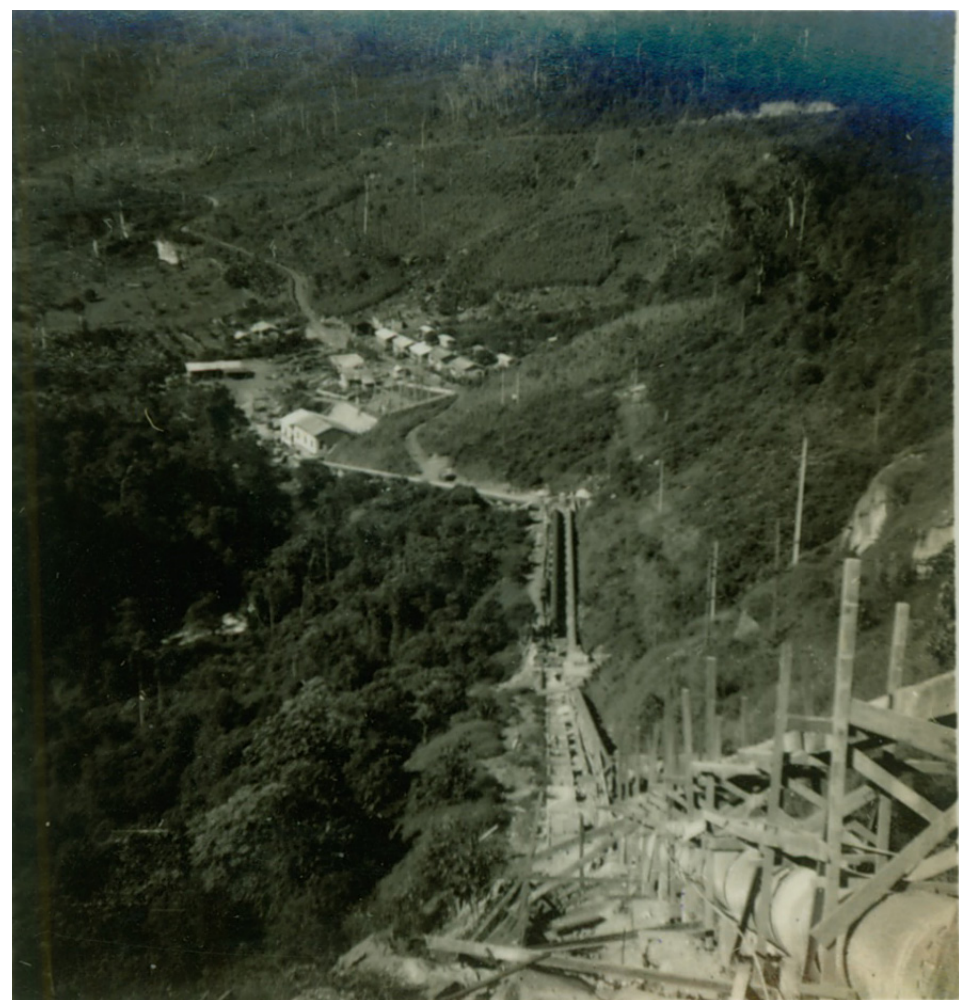

Fonte: Acervo Museu Histórico de Londrina - UEL. ${ }^{39}$

\footnotetext{
${ }^{38} \mathrm{~A}$ política indigenista no contexto do SPI (1910-1967) era a de transformar o índio em trabalhador nacional, sujeito engajado e produtivo, na perspectiva de homogeneização cultural. Ver mais detalhes em: SOUZA LIMA, Antonio Carlos de. $O$ governo dos índios sob a gestão do SPI. In: CUNHA, 1992, op. cit., p. 155-172.

${ }^{39}$ Foto retirada na década de 1940 pelo engenheiro responsável pela construção da usina. Ver: ACERVO FOTOGRÁFICO, op. cit.
} 
As entrevistas dos Kaingang revelam detalhes das atividades realizadas para a abertura dos caminhos para o assentamento do empreendimento hidrelétrico, como o do senhor Tapixi, Kaingang, morador atualmente na TI Apucaraninha.

Em 1947 eu morava no Pari Paró, quando começou a fazer o picadão, pra começar a fazer a usina, eu morava ali. Tinha umas tapera veia, nós se acampemos em umas casas veias, tudo caído assim, que eu não sei nem explicar pra você de quem que era aquelas moradias. Eu via eles passando e fazendo os picadão e tal. Nós cortava tora, meu pai pegou uma empreita de corta tora, um trançador sabe, aí nos acampamo no Pari Paró, fica entre meio Tamarana e Apucaraninha. Aí nos acampemo ali e aí eles começaram a fazer os picadão, aí eles trouxeram uns postes de madeira sabe, eles trazia no picadão e trazia arrastados esses postes. Pra fazer esses buracão e colocar esses postes, em uma terra bem vermelha e cada buraco daquele deixava um poste. Aí aqui, por exemplo, era o nosso rancho e daí meu pai vinha pelo picadão e derrubava um pinheiro pra lá, derrubava outro pra cá, derrubava e ia traçando com o trançador, aí eu vinha trazer almoço para o meu pai e era uma terra bem vermelha. De manhã cedo amanhecia cerração, neblina, aí eu vim, aí chegava naqueles buracos eu andava , aí eu andava por cima daqueles postes, descalço, então ficava bem o sinal do meu rastro em cima do poste, então quando eu voltava aí meu pai não deixava voltar aí eu ficava com ele até a tarde no mato, era ele mais dois índios, aí eu ficava até a tarde com ele lá no mato, aí quando nos voltava a onça tinha passado em cima do meu rastro dentro do poste, aí estava o rastro da onça que pisou em cima do meu rastro. ${ }^{40}$

O senhor José Bonifácio, Kaingang que sempre morou na área indígena do Apucarana, passando por diferentes Emãs, ratifica o trabalho indígena nas obras de construção da usina.

[...] Foi, foi. Que meu avô sempre contava essa história, sabe, trabalhou uns par de índio ali dentro, [...] na estrada que descia lá embaixo, onde tem a sede lá embaixo. Onde tem a casinha de força. Tem um veio que ajudou lá e ainda ta vivo né, tá bem veinho já, o Raul. Só que ele não sabe conversar bem agora. Então, ele trabalhou muito ali sabe, ele ganhava diária, a Copel

${ }^{40}$ TAPIXI (2017). Entrevista com João Maria Rodrigues Tapixi. Entrevistador: NOVAK, Éder da Silva. Terra Indígena Apucaraninha - Município de Tamarana, 28 de março de 2017. 
pagava diária pra ele, ele ajudou a construir, a fazer a estrada, com enxadão e picareta assim, depois que entrou as máquinas ali, depois que eles tiraram tudo as pedras redondas que tinha ali, eles rancava tudo, sabe, então, daí depois entrou as máquinas lá e limparam, então, daí quem trabalhou hoje lá dentro é um tal de Raul. Raul Pereira, ele está bem velhinho já ele não sabe nem conversar tem que ter uma pessoa pra traduzir as palavras que ele passa pra gente. ${ }^{41}$

As informações convergem quanto ao trabalho indígena na construção da usina. O pagamento em dinheiro ou em mercadorias despertaram o interesse de algumas famílias Kaingang que se deslocaram para a área próxima ao Salto Apucaraninha.

A memória indígena destaca também as relações sócio históricas entre os sujeitos presentes na região do Salto Apucaraninha, a partir de 1946, quando iniciou a construção da usina. Relações que foram intensificadas a partir de 1952, com a instalação da nova sede do PI Apucarana na mesma localidade. Os Kaingang afirmam que realizavam trocas dos seus artesanatos por diferentes produtos, objetos e alimentos com os empregados da usina, conforme relata dona Gilda Kuitá.

Tinha uma família lá, que tinha uma casa, que minha mãe gostava de ir lá visitar, eu não lembro o nome, mas ela sempre ia lá. Eles tinha um salão lá embaixo. Porque era muita gente. Lá embaixo eles tinha um campinho lá, uma igreja, um salãozinho. Aí os índios iam lá, antes disso, quando eles não tinham salão, começaram a construir, eles vinham aqui nos índios, dança aqui no Toldo. Tinha essa integração, eles vinham aqui no Toldo. ${ }^{42}$

Portanto, as entrevistas denotam as relações sócio históricas entre os indígenas e os empregados da usina, travando relações de aproximação e de amizades, nos bailes, festas, confraternizações, jogos de futebol, missas e cultos e nas pescarias, conforme narra o senhor Elói Zacarias, de quase 90 anos, que desempenhou o papel de cacique nos anos da construção da UHE.

Eles eram amigos dos índios. É, era, quando os índios fazia baile aí eles vinha e dançava com índios, era assim, mas despois eles tinham campo de bola, naquele tempo também jogava muita

${ }^{41}$ JOSÉ BONIFÁCIO (2017). Entrevista com José Ekór Bonifácio. Entrevistador: NOVAK, Éder da Silva. Terra Indígena Apucaraninha - Município de Tamarana, 29 de março de 2017.

${ }^{42}$ GILDA KUITÁ (2017). Entrevista com Gilda Kuitá. Entrevistador: NOVAK, Éder da Silva. Terra Indígena Apucaraninha - Município de Tamarana, 29 de março de 2017. 
bola, eu ajudava jogar bola com eles, bola assim, um dia eles falaram assim pra mim Elói você tá jogando muito com nós. ${ }^{43}$

Obviamente essas relações não foram apenas harmoniosas, conforme ressalta dona Gilda Kuitá.

Fizeram, os operários, os operários né, quem tava trabalhando lá, porque na usina assim vai muita gente né. Isso deu muito transtorno né. Assim, com as índias né, os encontros com as índias. ${ }^{44}$

As entrevistas indicam a ocorrência de muitos relacionamentos entre os operários da usina e membros da comunidade indígena, gerando situações conflituosas. Essas questões são importantes para compreender as disputas internas e o jogo político que caracterizam as diversas etnias. Suas relações com o não-indígena e entre os seus membros devem ser mediadas pela compreensão da sua historicidade.

Fotografia 3: Indígenas e empregados da usina em dia de festa no Posto Indígena Apucarana

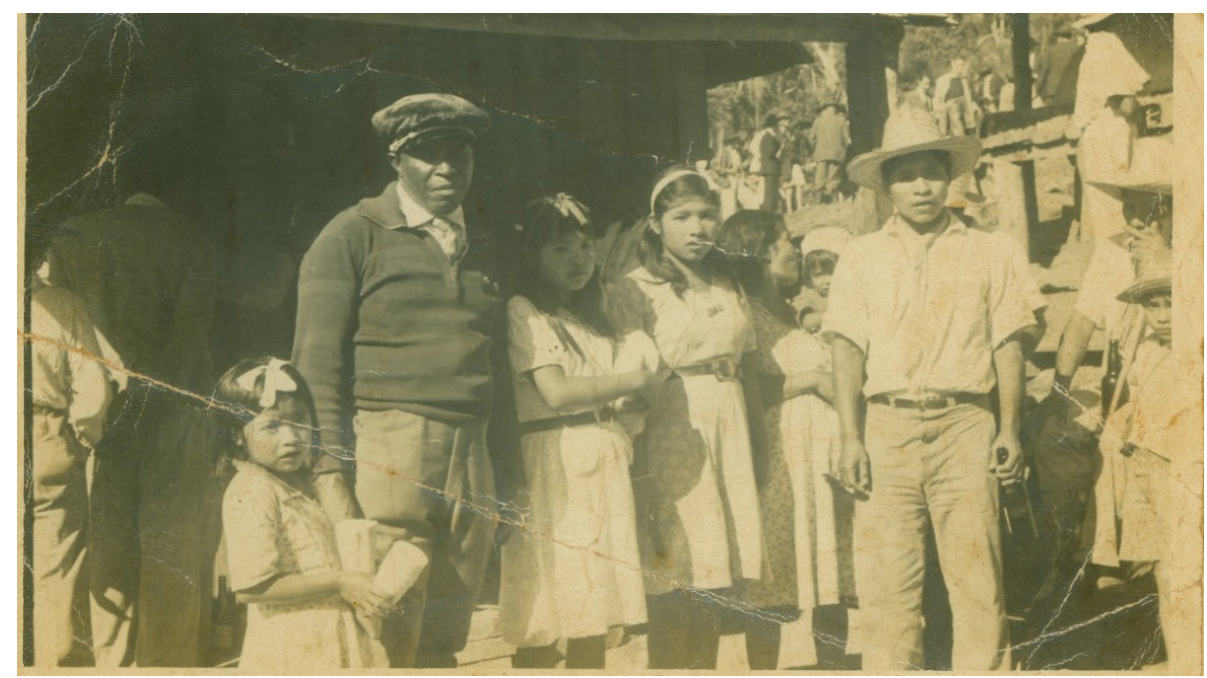

Fonte: Acervo Museu Histórico de Londrina - UEL. ${ }^{45}$

\footnotetext{
${ }^{43}$ ELÓI ZACARIAS (2017). Entrevista com Elói Zacarias Nogueira Pipir. Entrevistador: NOVAK, Éder da Silva. Terra Indígena Apucaraninha - Município de Tamarana, 29 de março de 2017.

${ }^{44}$ GILDA KUITÁ (2017), op. cit.

${ }^{45}$ Foto retirada na década de 1940 pelo engenheiro responsável pela construção da usina. Ver: ACERVO FOTOGRÁFICO, op. cit.
} 
Nessas interações entre a comunidade indígena e os empregados da EELSA acabavam ocorrendo os diálogos sobre o andamento das atividades da usina. Quando as obras foram encerradas, o engenheiro responsável - conhecido como Luís Gaúcho - disse aos indígenas que a hidrelétrica lhes pertencia, que era para eles trabalharem na usina, mas que precisavam de estudos. Isso aparece em várias narrativas dos Kaingang, como a do senhor Tapixi a seguir.

Você já conversou com Elói? O Elói sabe detalhadamente da usina, o cara que fez a usina chamava Luís Gaúcho, o Elói sabe do começo até o fim da usina, ele lembra quando começou a usina, quando o cara, o engenheiro terminou a usina, ele veio e entregou para o chefe do posto e falou lá tá terminado a usina e assim o Elói passou para mim, tá terminado a usina e a usina é dos índios e tá na terra dos índios e eu tô indo embora construir uma usina em Itaipu. O Elói nesse tempo era cacique, mas nesse tempo já tinha a sede do posto aqui. Já era aqui. Ele conhece o final da usina sabe. Na usina ele sabe tudo, o Elói. ${ }^{46}$

O Sr. Elói Zacarias, que era liderança indígena na época da construção da usina, reafirmou essas informações.

Eu conheço quem sentou a usina, chamava, ele chamava Luís, Luís Gaúcho, parece que já é morto. É, quando estava trabalhando com o Alan, um dia, ele veio, aí tinha muito, muito branco ali que tava trabalhando na usina [...]daí um dia eu vi Gaúcho vim umas horas assim, mais tarde um pouco, vinha subindo com três, o Alan mandou ele sentar aí, o Alan falou pra ele, não, o Luís falou assim, o Alan agora vou trabalhar pro senhor, só que o serviço eu já fiz tudo, tudo, olha essa usina eu trabalhei pra mim assentar, tudo, tudo, a usina tá novo, óia trabalhei cinco anos, trabalhei cinco ano aí, mas essa usina tá no terreno dos índios, os índios ganharam, então, os índios que vão trabalhar, mas naquele tempo não tinha nem professor pra estudar os índios que nem sabia de ler, não sabia de nada, nada, nada, naquele tempo, o Alan abaixou a cabeça daí ele falou pro Luís, mas Luís os índios não é estudado, não sabe trabalhar na máquina, não sabe ler, não sabe nada, esse que tá duro pra mim, daí entraram os brancos, entraram os brancos [...] Daí o Gaúcho falou assim pro Alan, os índios que podia, eles que ia trabalhar, por que tá no terreno deles aí, terreno deles, o terreno é deles, então, a usina já tá pronto aí, então, eles que ia trabalhar, daí, mas

${ }^{46}$ TAPIXI (2017), op. cit. 
ninguém não sabia nem trabalhar, ler né, não sabia de nada, aí branco que entrou né, oitenta anos o branco ganhando e os índios ficou sem nada. ${ }^{47}$

Segundo os Kaingang entrevistados essa questão sobre a usina estar em território indígena sempre esteve presente nas reuniões das lideranças e nas conversas da maior parte da comunidade da TI Apucaraninha. A passagem abaixo expressa o sentimento de injustiça e de indignação dos Kaingang na atualidade, pelo fato de ter que pagar por algo que é gerado dentro do seu território.

Porque aqui tem uma coisa que eu não concordo sabe, não concordo, [...] como que pode acontecer, como que uma coisa que eu não concordo aqui é o índio pagar luz. Eu não concordo, a usina tá dentro do território indígena, é indígena, como é que a gente vai poder pagar, eles faz uma fortuna, eles tem, como é que eu vou falar para o senhor, eles tem um troféu de ouro dentro da comunidade indígena, que mina dinheiro minuto por minuto, segundo por segundo, hora por hora, dia por dia, ano por ano. Dia e noite sem parar, como é que a gente vai ter que pagar essa luz meu Deus do céu? ${ }^{48}$

Conquanto, graças aos deslocamentos para as proximidades da usina, ainda no final da década de 1940, os Kaingang garantiram a posse daquelas terras (hoje corresponde a atual sede da TI Apucaraninha). Consequentemente, as relações sociais estabelecidas com os empregados da usina, mediadas ou não pelo órgão indigenista, despertaram o sentimento inicial de injustiça pela presença da usina em suas terras sem algum retorno à comunidade indígena. Posteriormente, os Kaingang buscaram conhecer de forma mais acentuada os mecanismos de funcionamento da sociedade não indígen $a^{49} \mathrm{e}$, convivendo de forma mais intensa com esta, passaram a defender a ideia de apropriação da usina. Esse processo culminou nos TACs assinados em 2002 e 2006, conforme apresentados na introdução.

Como já dito, não se trata de negar os impactos de uma hidrelétrica em áreas pertencentes aos povos indígenas. Outrossim, é preciso analisar as

\footnotetext{
${ }^{47}$ ELÓI ZACARIAS (2017), op. cit.

${ }^{48}$ TAPIXI (2017), op. cit.

${ }^{49} \mathrm{Na}$ verdade, os povos indígenas sempre buscaram conhecer os mecanismos de funcionamento da sociedade não indígena, desde os tempos coloniais, buscando assegurar e obter novos direitos. Ver mais detalhes em: ALMEIDA, 2010, op. cit.
} 
ações e estratégias dos Kaingang frente ao empreendimento hidrelétrico e seus representantes.

A EELSA e depois a COPEL usufruíam dos recursos naturais da comunidade, os quais viabilizavam o aproveitamento, sem dar, provavelmente, a suficiente contrapartida, pois a remuneração parece ter sido pouco significativa, tanto perante o retorno propiciado pela UHE Apucaraninha, quanto em relação às necessidades materiais da comunidade. [...] Com o tempo a percepção de injustiça cresceu entre indígenas, técnicos e agentes institucionais envolvidos em trabalhos de assessoria naquela área (FUNAI, universidades, ongs, igrejas etc.), daí um certo ressentimento presente nas referências a COPEL de parte destes atores. Esta situação e a correlata insatisfação da comunidade e de seus parceiros era prejudicial à imagem da empresa. ${ }^{50}$

Indubitavelmente, não se pode afirmar que apenas na virada do século XX para o XXI - no contexto das assinaturas dos TACs - que os Kaingang do Apucarana estabeleceram suas políticas frente a concessionária de energia elétrica, em virtude da presença da usina em seu território. Eles não agiram somente após a publicação dos documentos internacionais - Agenda 21 e Convenção 169 (OIT) - ou de toda a discussão sobre "Hidrelétricas e Povos Indígenas" que surgiram nos anos 1970 e que culminaram em importantes medidas adotadas na CF de 1988. As ações indígenas estiveram/estão presentes desde os tempos iniciais de construção da usina, conforme demonstrado. Obviamente, que o sentimento de apropriação da hidrelétrica foi crescendo no interior da comunidade indígena, que se sentiu (sente) injustiçada e passou a definir uma nova política na tratativa com a concessionária de energia elétrica.

Portanto, o contexto mais recente permitiu à comunidade Kaingang da TI Apucaraninha a organização de novas estratégias na luta por seus direitos. As últimas três décadas têm demonstrado intensos debates em torno da temática "Hidrelétricas e Povos Indígenas", sendo que os indígenas têm acompanhado de perto e participado das discussões e formulações da normatização e da regulamentação da questão, a partir da CF de 1988. Entretanto, mesmo anterior a tal contexto, os indígenas também se portaram enquanto sujeitos. 0 estudo apresentado evidencia a percepção indígena do elemento novo presente em seu território - a usina - e uma série de ações para assegurar seus direitos e obter benefícios diante dessa novidade, por meio de acordos e alianças, mas também conflitos e tensões.

${ }^{50} \mathrm{COPEL}$, 2006. Relatório da COPEL. Caixa N30712, Fls. 40-47. Biblioteca da COPEL, Polo Atuba, Curitiba. 2006. 
A UHE Apucaraninha possui uma história bastante conturbada, sendo palco de vários conflitos de interesses, tendo por um lado a Comunidade Indígena reivindicando constantemente reajustes nos valores pagos anualmente pela utilização da área onde está localizada a usina, e do outro a COPEL que sempre procurou atender, dentro do possível e da legalidade, as reivindicações apresentadas. $^{51}$

Em todo este processo a participação da comunidade indígena precisa ser destacada. Como visto, desde o princípio das obras da usina, os Kaingang buscaram se relacionar com os empregados da EELSA, trocando e vendendo seus artesanatos e outras mercadorias, realizando determinadas atividades enquanto mão de obra remunerada. Antes mesmo dos representantes do órgão indigenista ter ciência das obras da usina no território dos indígenas, estes já se articulavam com o novo sujeito presente em seu cotidiano, como já faziam com os madeireiros, arrendatários e outros que marcavam presença em suas terras.

A instalação da UHE do Apucaraninha, em meados do século XX, no Território Indígena Apucarana, não pode ser analisada com uma visão maniqueísta da história ou com teorias previamente elaboradas, que dicotomizam as relações entre indígenas e não-indígenas, adjetivando os sujeitos envolvidos como bons ou maus, conforme pressupostos teóricos utilizados. As relações sócio históricas entre indígenas e não-indígenas não devem ficar ancoradas nessas versões simplificadoras da história, que promovem os dualismos normalmente perceptíveis quando se aborda a história indígena no Brasil. Também não se deve utilizar daquela visão essencialista, não recorrente à ideia de dinamicidade cultural e ao processo de transformação na forma de vida dos indígenas. A relação com a usina foi mais um episódio de readequação no modo de viver dos Kaingang, como tantos outros enfrentados ao longo de sua história. Compreender essa historicidade é um caminho para evitar análises do presente, que ainda insistem em enfatizar a ideia de oportunismo dos indígenas, superando os velhos estereótipos sobre a história e cultura indígena e contextualizando, assim, sua luta.

${ }^{51}$ COPEL, 06/10/2003. Relatório gerencial da COPEL no 004/2003. Caixa N30711, Fl. 110. Biblioteca da COPEL, Polo Atuba, Curitiba. 2003. 


\section{Considerações finais}

A primeira UHE construída em território legalmente reservado aos indígenas, no Brasil, promoveu um entrelace de diferentes sujeitos, participantes de uma mesma trajetória histórica, embora nem sempre mediadas por relações simétricas. Procurou-se dar maior atenção ao protagonismo indígena, embora se reafirme a necessidade de uma análise das ações de todos os sujeitos presentes, devidamente conectadas e contextualizadas, como enfatiza Oliveira. ${ }^{52}$

A UHE do Apucaraninha representou uma nova fase da conquista das frentes colonizadoras, perante os territórios indígenas do Apucarana, no rio Tibagi, estado do Paraná. A historicidade dos Kaingang e sua leitura de mundo permitiram que os indígenas compreendessem aquele contexto histórico, desenvolvendo, assim, suas estratégias políticas.

Estratégias que não foram uniformes, mas que se intercruzaram em diferentes ações, desde o início das obras do empreendimento hidrelétrico no Salto Apucaraninha. Primeiramente, o deslocamento de algumas famílias indígenas até as proximidades do canteiro de obras, constituindo seus Toldos no local. Contudo, muitos outros grupos permaneceram em seus Emãs de outrora, compreendendo uma vasta área geográfica, conforme Mapas apresentados.

Em segundo, o deslocamento indígena e a construção de Toldos na margem direita do rio Apucaraninha influenciaram decisivamente a ação do órgão indigenista em mudar a sede do PI Apucarana para próximo da usina em construção. O local corresponde a atual TI Apucaraninha.

Terceiro, apenas no final da década de 1960, a maior parte dos indígenas se estabeleceu nas proximidades da nova sede do Posto e da usina, à medida que o órgão indigenista foi estruturando a sede do PI Apucarana, com escola, posto de saúde, construção de casas aos indígenas, oferta de trabalho remunerado, eletricidade etc.

Por último, os Toldos formados pelos primeiros Kaingang que se aproximaram das obras do empreendimento hidrelétrico, na margem direita do Salto Apucaraninha, asseguraram aos indígenas a posse das terras adjacentes à usina. As relações sociais estabelecidas com os empregados da EELSA e seus familiares despertaram na comunidade indígena o sentimento de apropriação da usina, situada desde o início em área pertencente aos Kaingang. Esse sentimento movimentou (e ainda movimenta) a comunidade indígena local em

${ }^{52}$ OLIVEIRA, João Pacheco de. O nascimento do Brasil e outros ensaios: "pacificação", regime tutelar e formação de alteridades. Rio de Janeiro: Contra Capa, 2016. 
suas reivindicações junto à concessionária de energia elétrica. Estas reivindicações foram (são) fundamentadas por toda a historicidade Kaingang, que obtiveram algumas conquistas nas revisões dos contratos junto à COPEL e nas assinaturas dos citados TACs em 2002 e 2006. Os sentimentos de indignação e de injustiça, expressos nas entrevistas, revelam que as ações e as relações entre a concessionária, os Kaingang e o órgão indigenista, geralmente tensas e conflituosas, não tem data para acabarem.

Inegavelmente, o processo de esbulho do Território Indígena Apucarana e a presença da usina trouxeram mudanças e impactos consideráveis na forma de vida de todos os Kaingang daquele local. Entretanto, essas transformações precisam ser compreendidas por meio da ideia de dinamicidade cultural, pois os povos indígenas não são portadores de uma cultura estática, mas que se transforma a cada novo contexto histórico, promovendo novas interpretações e recriando suas formas de vida.

A narrativa apresentada procurou distanciar-se das abordagens dualistas, que polarizam indígenas e não-indígenas, como se a história não possibilitasse a interligação de suas ações. A análise também não compartilhou da ideia de história de mão única, mas evidenciou o protagonismo indígena, destacando os Kaingang enquanto sujeitos históricos. Finalmente, espera-se ter contribuído para o entendimento das questões atuais, envolvendo os representantes da COPEL e os Kaingang da TI Apucaraninha, retirando alguns estereótipos que buscam descaracterizar a luta desta comunidade. Ao mesmo tempo, estima-se ter cooperado com o presente debate em torno da questão "Hidrelétricas e Povos Indígenas".

\section{Referências}

ACERVO FOTOGRÁFICO. Coleção Luiz Muraska. Museu Histórico de Londrina Padre Carlos Weiss - Universidade Estadual de Londrina (UEL).

ALMEIDA, Maria Regina Celestino de. Os índios na história do Brasil. Rio de Janeiro: Ed. FGV, 2010.

ANDREOLI, Arturo. A história da energia elétrica no Estado do Paraná. Companhia Paranaense de Energia Elétrica (COPEL). Histórico. Curitiba: 2004.

BALANDIER, Georges. El concpeto de situación colonial. Ciudad de México, 1972. 
BIASETTO, Eliane Aparecida. O Rio Tibagi e suas representações: a polêmica da água e o desenvolvimento do Projeto Tibagi (1970-2000). Dissertação (Mestrado em História Social), Universidade Estadual de Londrina, Londrina. 2014.

COPEL, 2006. Relatório da COPEL. Caixa N30712, Fls. 40-47. Biblioteca da COPEL, Polo Atuba, Curitiba. 2006.

COPEL, 06/10/2003. Relatório gerencial da COPEL no 004/2003. Caixa N30711, Fl. 110. Biblioteca da COPEL, Polo Atuba, Curitiba. 2003.

CUNHA, Manuela Carneiro da. (Org.). História dos índios no Brasil. São Paulo: Cia. das Letras, 1992.

DOMINGUES, William César Lopes Cachaça. Concreto e Sangue! Saúde, Alcoolismo e Violência. Povos Indígenas no Contexto da Hidrelétrica de Belo Monte. Dissertação (Mestrado) - Universidade Federal do Pará, Instituto de Filosofia e Ciências Humanas, Programa de Pós-Graduação em Antropologia, Belém, 2017.

DUARTE, Amauri. Projeto da Usina Hidrelétrica São Jerônimo: conflitos e contrastes. Dissertação (Mestrado em Geografia), Universidade Estadual de Maringá, Maringá. 2004.

ELÓI ZACARIAS (2017). Entrevista com Elói Zacarias Nogueira Pipir. Entrevistador: NOVAK, Éder da Silva. Terra Indígena Apucaraninha - Município de Tamarana, 29 de março de 2017.

GILDA KUITÁ (2017). Entrevista com Gilda Kuitá. Entrevistador: NOVAK, Éder da Silva. Terra Indígena Apucaraninha - Município de Tamarana, 29 de março de 2017.

HELM, Cecília M. Vieira. Conflitos Sociais entre Indígenas e não Indígenas no Processo de Negociação sobre Compensações de Usinas Hidrelétricas implantadas em Terras Indígenas. In: $1^{\circ}$ Encontro Ciências Sociais e Barragens. Universidade Federal do Rio de Janeiro, IPPUR/UFRJ. Rio de Janeiro, 08 a 10 de junho de 2005.

JOSÉ BONIFÁCIO (2017). Entrevista com José Ekór Bonifácio. Entrevistador: NOVAK, Éder da Silva. Terra Indígena Apucaraninha - Município de Tamarana, 29 de março de 2017.

MONTEIRO, John Manuel. o desafio da história indígena. In: SILVA, Aracy Lopes da; GRUPIONI, Luís Donizete Benzi (Orgs.). A temática indígena na Escola. MEC, Brasília, 1995, p. 221-228.

MONTEIRO, John Manuel. Os negros da terra: índios e bandeirantes nas origens de São Paulo. São Paulo: Companhia das Letras, 1994. 
MOTA, Lúcio Tadeu. As guerras dos índios Kaingang: a história épica dos índios Kaingang no Paraná (1769-1924). 2. ed. Maringá: Eduem, 2009.

MOTA, Lúcio Tadeu. As colônias indígenas no Paraná provincial. Curitiba: Aos Quatro Ventos, 2000.

MOTA, Lúcio Tadeu. A Guerra de Conquista nos Territórios dos Índios Kaingang do Tibagi. Revista de História Regional. Ponta Grossa, vol. 1, p. 187-207, jan./jun. 1997.

NOVAK, Éder da Silva. Emã e Tekoha: territórios indígenas e a política indigenista. Curitiba: Appris, 2019.

NOVAK, Éder da Silva. Os Kaingang e a reestruturação do Território Indígena Apucarana (PR) no século XX. Territórios e Fronteiras (UFMT. Online), v. 11, 2018, p. 279-307.

NOVAK, Éder da Silva. Os Kaingang do Apucarana, o órgão indigenista e a usina hidrelétrica do Apucaraninha. Tese (Doutorado em História). Universidade Federal da Grande Dourados, Dourados - MS, 2017.

NOVAK, Éder da Silva; MOTA, Lúcio Tadeu. A política indigenista e os territórios indígenas no Paraná (1900-1950). Revista Fronteiras. Dourados, MS. v. 18, n. 32. p. 76-97. jul./dez. 2016.

OLIVEIRA, João Pacheco de. O nascimento do Brasil e outros ensaios: “pacificação”, regime tutelar e formação de alteridades. Rio de Janeiro: Contra Capa, 2016.

OLIVEIRA, João Pacheco de. O nosso governo: os Ticunas e o regime tutelar. São Paulo: Marco Zero, 1988.

OLIVEIRA, João Pacheco de; COHN, Clarice. (Orgs.). Belo Monte e a Questão Indígena. Brasília-DF: ABA. 2014.

PAZ, Luciana Rocha Leal da. Hidrelétricas e Terras Indígenas na Amazônia:

Desenvolvimento Sustentável? Tese (Doutorado) - Universidade Federal do Rio de Janeiro (COPPE/UFRJ), Rio de Janeiro, 2006.

PEREIRA (2017). Entrevista com Raul Pereira. Entrevistador: NOVAK, Éder da Silva. Terra Indígena Apucaraninha - Município de Tamarana, 28 de março de 2017.

RAMOS, Luciana Maria de Moura. Vénh Jykrée Ke Há Han Ke: Permanência e Mudança do Sistema Jurídico dos Kaingang no Tibagi. Tese (Doutorado em Antropologia Social), Universidade de Brasília, Brasília. 2008. 
RECCO, Rogério. Clareira Flamejante: o Norte do Paraná antes e após o advento da energia elétrica. Maringá: Gráfica e Editora Midiograf, 2007.

RODRIGUES, Diego Campos Arruda. Concepções e práticas agroflorestais na terra indígena Kaingang Apucaraninha (Paraná). Dissertação (Mestrado em Ciências Sociais), Universidade Estadual de Londrina, Londrina. 2008.

SIQUEIRA, Márcia D. et al. Um século de eletricidade no Paraná. Curitiba: Universidade Federal do Paraná, 1994.

SOUZA LIMA, Antonio Carlos de. Um grande cerco de paz: poder tutelar e indianidade no Brasil. Petrópolis: Vozes, 1995.

SOUZA LIMA, Antonio Carlos de. O governo dos índios sob a gestão do SPI. In: CUNHA, Manuela Carneiro da. (Org.). História dos índios no Brasil. São Paulo: Cia. das Letras, 1992, p. 155-172.

SPI, 07/12/1967. Relatório Mensal de Novembro de 1967. Filme 71, Fotograma 1720. Museu do Índio, Rio de Janeiro.

SPI, 22/12/1950. Atas de Reunião. Filme 48, Fotograma 1468. Museu do Índio, Rio de Janeiro.

SPI, 12/10/1950. Ofício no 26 e Croquis. Filme 76, Fotogramas 269-272. Museu do Índio, Rio de Janeiro.

SPI, 14/03/1950. Croquis. Filme 76, Fotograma 251. Museu do Índio, Rio de Janeiro. SPI, 30/03/1947. Relatório SPI. Filme 73, Fotograma 1644. Museu do Índio, Rio de Janeiro.

TAPIXI (2017). Entrevista com João Maria Rodrigues Tapixi. Entrevistador: NOVAK, Éder da Silva. Terra Indígena Apucaraninha - Município de Tamarana, 28 de março de 2017.

TOMMASINO, Kimiye. A história dos Kaingang da bacia do Tibagi: uma sociedade Jê meridional em movimento. Tese (Doutorado em Antropologia), Universidade de São Paulo, São Paulo. 1995.

Artigo enviado para publicação em 02/05/2020

Artigo aprovado para publicação em 09/10/2020 